\title{
TRANSLITERASI, SERAPAN, DAN PADANAN KATA: UPAYA PEMUTAKHIRAN ISTILAH DALAM BAHASA INDONESIA
}

\author{
Syihaabul Hudaa \\ Institut Teknologi dan Bisnis Ahmad Dahlan \\ Posel: syihaabul@stiead.ac.id
}

\begin{abstract}
Indonesian has a word formation variant as an effort to update the vocabulary. However, not many people who use language know the terms transliteration, absorption and equivalent words in Indonesian. This makes a word accepted without knowing the original word form. The purpose of writing this article is to describe vocabulary written in the form of transliteration, absorption, and also equivalent words in Indonesian. The methodology used in this study is content analysis by focusing on the text used as the object of study. The results of research findings conducted by researchers are the existence of vocabulary in the form of transliteration, absorption, and equivalents that are often used in communication. The researcher gives an explanation of a word that is included in transliteration, absorption, and equivalence.
\end{abstract}

Keyword: word form; language update; language terms.

\begin{abstract}
Abstrak
Bahasa Indonesia memiliki varian pembentukan kata sebagai upaya pemutakhiran kosakatanya. Akan tetapi, tidak banyak masyarakat pengguna bahasa yang mengetahui adanya istilah transliterasi, serapan dan padanan kata di dalam bahasa Indonesia. Hal ini membuat suatu kata diterima tanpa diketahui bentuk kata aslinya. Tujuan penulisan artikel ini untuk memaparkan kosakata yang ditulis dalam bentuk transliterasi, serapan, dan juga padanan kata di dalam bahasa Indonesia. Metodologi yang digunakan dalam penelitian ini adalah analisis isi dengan memfokuskan pada teks yang dijadikan objek kajian. Hasil temuan penelitian yang dilakukan oleh peneliti yaitu adanya kosakata dalam bentuk transliterasi, serapan, dan padanan yang sering digunakan dalam komunikasi. Peneliti memberikan penjelasan mengenai suatu kata yang termasuk ke dalam transliterasi, serapan, dan padanan.
\end{abstract}

Kata Kunci: bentuk kata; pemutakbiran bahasa; istilah bahasa.

\section{PENDAHULUAN}

Bahasa Indonesia mengalami perkembangan melalui pemutakhiran kosakatanya. Kosakata bahasa Indonesia terus ditambahkan dengan tujuan memperkaya khazanah bahasa Indonesia. Hal tersebut dikarenakan istilah asing masih diutamakan dalam praktik berkomunikasi, baik secara lisan maupun tulisan. Istilah tersebut memudarkan pesona bahasa Indonesia yang seharusnya diutamakan dalam kegiatan sehari-hari. Misalnya saja, istilah smartphone lebih sering digunakan daripada kata gawai yang merupakan padanannya.

Arus sibernitas memungkinkan bahasa Indonesia berkembang pesat menambah jumlah kosakata yang masuk di dalam KBBI. Pemadanan kata asing ke dalam bahasa merupakan suatu ciri khas tersendiri dari bahasa Indonesia yang tidak dimiliki oleh bahasa asing lainnya (Hudaa, 2017). Akan tetapi, sebagian masyarakat tidak mengetahui adanya bentuk pemadanan istilah dalam bahasa. Bahkan, istilah serapan yang seharusnya dituliskan dengan benar seperti kata musala masih dituliskan dalam bentuk transliterasinya yaitu musholla. Ha ini tentu saja tidak sesuai dengan kaidah penggunaan bahasa Indonesia yang benar. 
Padanan dalam terjemahan selalu dikaitkan dengan fungsi teks dan bentuk terjemahan (Sulistyowati, 2015). Dengan kata lain, padanan muncul sebagai suatu bentuk pengganti dari istilah asing menjadi istilah bahasa Indonesia. Bentuk kata dalam padanan dapat dikatakan memiliki fungsi yang sama dengan bahasa asing, tetapi istilah yang digunakan sudah sesuai dengan kaidah bahasa Indoenesia. Untuk itu, padanan dapat menjadi alternatif istilah yang tepat dalam bahasa Indonesia.

Masuknya era digital dan MEA memengaruhi penggunaan bahasa dalam berkomunikasi. Sebagai contoh bahasa asing dapat ditemukan di media sosial, media cetak, dan interaksi langsung. Hal tersebut tentu berdampak pada pudarnya pesona bahasa Indonesia sebagai bahasa nasional. Setiap orang yang datang ke Indonesia seharusnya menggunakan bahasa Indonesia agar mempelajari budaya yang terdapat di dalamnya (Hudaa, 2017). Akan tetapi, justru penggunaan bahasa asing lebih dominan digunakan dalam proses interaksi di masyarakat.

Modernitas menjanjikan perkembangan dalam pelbagai aspek, salah satunya adalah bahasa. Namun, bahasa Indonesia yang ditargetkan sebagai bahasa internasional tidak menjadi prioritas orang Indonesia itu sendiri. Iklan dan spanduk yang berada di jalan, lebih percaya dengan bahasa pemasaran yang menggunakan bahasa Inggris. Padahal, dalam bahasa Indonesia ada istilah transliterasi dan padanan kata yang menjadikan bahasa Indonesia memiliki pengganti bahasa aslinya.

Tujuan penulisan artikel ini adalah untuk menjelaskan bahwa dalam bahasa Indonesia kita memiliki transliterasi, serapan, dan padanan yang dapat dijadikan acuan dalam penulisan kata. Peneliti mengkaji istilah asing yang masih konvensional digunakan di Indonesia dan mencari transliterasinya, serapan, atau mungkin padanan katanya yang dapat digunakan sebagai pengganti bahasa aslinya. Penelitian ini menggunakan pendekatan analisis isi dan sumber kepustakaan lainnya yang berasal dari KBBI, Pedoman Umum Pembentukan Istilah, dan Tata Bentuk Bahasa Indonesia. Selain itu, peneliti akan memberikan penjelasan tentang kosakata yang sudah dimutakhirkan dan ditemukan dalam KBBI.

\section{METODE PENELITIAN}

Penelitian ini menggunakan analisis isi untuk mengkaji setiap teks yang terdapat di dalamnya. Analisis isi menitikberatkan pada teks yang terdapat di dalamnya, sehingga peneliti dapat mengkaji secara mendalam (Emzir, 2012). Peneliti akan melakukan kajian dengan menghubungkan kosakata asing dengan transliterasi. Kemudian, peneliti akan menggunakan kamus dan Pedoman Umum Pembentukan Istilah sebagai referensi untuk memastikan bahwa kata tersebut dapat diterima dan digunakan dalam bahasa Indonesia.

\section{HASIL DAN PEMABAHASAN}

\section{Transliterasi}

Hudaa (2018) menyebut bahwa transliterasi merupakan suatu bentuk alih aksara dari huruf aslinya ke huruf latin (huruf alfabet dalam bahasa Indonesia). Istilah ini muncul untuk memudahkan masyarakat dalam penyebutan istilah asingnya. Akan tetapi, kata transliterasi 
yang digunakan di dalam bahasa Indonesia, belum sesuai dengan kaidah baku dalam KBBI. Sebagai contoh kata berikut ini.

\begin{tabular}{|c|c|}
\hline Adzan & Azan \\
\hline
\end{tabular}

Kata adz̧an di atas merupakan suatu bentuk transliterasi dari Arab-Latin dalam bahasa Indonesia. Akan tetapi, gabungan konsonan 'dz' tidak terdapat di dalam bahasa Indonesia, sehingga bentuk ini merupakan bentuk tidak baku. Apabila kita melihat KBBI, kata yang bakunya adalah azan, bukan adzan. Kata ini sudah lazim digunakan dan diketahui oleh masyarakat Indonesia, tetapi justru bentuk tidak baku dari kata ini yang sering digunakan.

Kata lainnya yang merupakan bentuk transliterasi dalam bahasa Indonesia dan sering digunakan adalah kata Ramadhan. Seperti yang sudah diketahui dalam PUEBI, bahwa gabungan huruf konsonan hanya ada huruf kh, sy, ny, dan ng. Untuk itu, gabungan konsonan $d h$ yang digunakan pada kata Ramadhan merupakan bentuk tidak baku dari kata Ramadan.

\begin{tabular}{|l|l|}
\hline Ramadhan & Ramadan \\
\hline
\end{tabular}

\section{Serapan}

Serapan dalam bahasa Indonesia merupakan suatu bentuk kaidah transliterasi yang penulisannya sudah disesuaikan dengan aturan baku dalam KBBI (Hudaa, 2018). Dengan kata lain, bentuk serapan dibuat berdasarkan aturan dalam KBBI, baik aspek kaidah penulisan yang benar secara lisan maupun tulisan. Bentuk serapan kata dalam bahasa Indonesia muncul sebagai penyempurnaan penulisan kata yang sebelumnya tidak tepat secara kaidah, menjadi tepat dalam praktik penulisan. Sebagai contoh, dalam aspek lisan kita sering mendengar kata 'qolbu' yang merupakan bentuk transliterasi Arab-berarti hati dalam bahasa Indonesia. Akan tetapi, penyerapan yang benar ke dalam bahasa Indonesia adalah kalbu bukan qolbu karena (qof) dalam bahasa Arab diserap menjadi huruf (k) dalam bahasa Indonesia. Contoh lainnya sebagai berikut.

\begin{tabular}{|c|c|}
\hline Aqiqah & Akikah \\
\hline
\end{tabular}

Di atas ada dua kata yang secara pengucapan memiliki kemiripan, hanya saja berbeda dalam penulisan. Kata aqiqah yang kerap digunakan ternyata merupakan bentuk transliterasi dari bahasa Arab dan diserap menjadi akikah. Selain itu, kata lain dalam bentuk serapan yang sering kali digunakan bentuk transliterasinya adalah kata 'aquarium'. Mengacu kepada proses penyerapan kata, kata tersebut merupakan bentuk tidak baku dan kata bakunya adalah 'akuarium'.

\section{Membedakan Transliterasi dengan Serapan}

Secara sederhana, kedua bentuk ini kadang dianggap serupa oleh masyarakat Indonesia. Akan tetapi, kedua bentuk ini memiliki perbedaan yang signifikan. Transliterasi hanya mengalih aksarakan bahasa aslinya ke dalam huruf Latin. Misalnya saja bahasa Arab ke huruf Latin atau huruf Mandarin ke huruf Latin agar mudah dibaca. Sebaliknya, serapan merupakan suatu bentuk transliterasi yang sudah disempurnakan sesuai dengan kaidah bahasa Indonesia yang benar. Sebagai contoh beberapa kata yang sudah dipaparkan sebelumnya seperti:Ramadhan-Ramadan, sholat-salat, musholla-musala, dll. Kata-kata tersebut merupakan suatu kata yang sudah dialih aksarakan dari bahasa aslinya menjadi 
suatu ejaan yang mudah dibaca. Unsur serapan dalam bahasa Indonesia merupakan suatu bentuk yang sempurna dikarenakan sesuai dengan kaidah bahasa Indonesia.

\section{Padanan}

Padanan merupakan suatu bentuk pemutakhiran bahasa Indonesia yang terbilang unik, dikarenakan memunculkan istilah baru dalam bahasa Indonesia. Padanan berbeda dengan kaidah transliterasi dan serapan kata dalam bahasa Indonesia. Bentuk kata padanan sudah tidak bisa ditelusuri kemiripan dengan bahasa aslinya. Misalnya saja kata mouse yang sering kita gunakan dipadankan dengan kata tetikus dalam bahasa Indonesia. Kata tetikus merupakan bentuk padanan kata dalam bahasa Indonesia karena tidak dapat ditelusuri kemiripan dengan kata asalnya. Tentu saja hal tersebut berbeda dengan unsur serapan yang masih dapat ditelusuri unsur transliterasinya..

Pembentukan istilah dalam bahasa Indonesia memiliki aturan di dalamnya. Istilah tersebut tidak dibuat tanpa dasar, melainkan melalui proses pembentukan istilah yang sudah disepakati. Penulisan istilah serapan itu dilakukan dengan atau tanpa penyesuaian ejaannya berdasarkan kaidah fonotaktik, yakni hubungan urutan bunyi yang diizinkan dalam bahasa Indonesia (PUPI, 2007). Istilah asing yang konvensional dipadankan menurut kaidah fonotaktik sesuai dengan bunyi yang lazim di Indonesia. Dengan demikian, istilah tersebut dapat digunakan dalam bahasa Indonesia.

\begin{tabular}{|c|c|}
\hline Stakeholder & Pemangku Kepentingan \\
\hline
\end{tabular}

Jika dicermati kata asing di atas sangatlah konvensional digunakan dalam bahasa Indonesia. Bahkan, istilah stakeholder lebih dikenal daripada kata padanannya yaitu 'pemangku kepentingan'. Kata tersebut dipadankan dengan standardisasi pembentukan istilah yaitu disesuaikan dengan bentuk aslinya yang merupakan nomina. Pemadanan kata di atas bertujuan untuk membuat suatu padanan istilah yang dapat digunakan secara konvensional.

\begin{tabular}{|c|c|}
\hline Benchmark & Tolak Ukur \\
\hline
\end{tabular}

Kata benchmark di atas merupakan suatu kata yang sudah umum digunakan untuk istilah gawai era modern. Misalnya saja untuk memeriksa atau memastikan perangkat yang digunakan berfungsi dengan baik, kata Antutu Benchmark rasanya tidak asing dalam istilah gawai era modern. Benchmark dipadankan dengan kata yang serupa yaitu 'tolak ukur' yang memang memiliki istilah yang serupa, yaitu kata sifat. Kata tersebut sudah dipadankan dan disesuaikan dengan kata yang tepat dalam bahasa Indonesia.

\begin{tabular}{|c|c|}
\hline Baby-Sitter & Pramusiwi \\
\hline
\end{tabular}

Kata baby-sitter secara umum diketahui oleh masyarakat Indonesia sebagai suatu istilah untuk orang yang merawat anak Balita. Namun, kata tersebut saat ini sudah memiliki kata yang dapat digunakan sebagai padanannya dalam bahasa Indonesia yaitu kata 'pramusiwi' yang merupakan suatu istilah untuk orang yang merawat anak Balita. Kata tersebut disesuaikan dengan kata aslinya yang merupakan kata benda dengan dipadankan dengan kata yang memang merujuk pada kata yang sama, yaitu kata 'pramusiwi'.

\begin{tabular}{|c|c|}
\hline Cumlaude & Dengan Pujian \\
\hline
\end{tabular}

Kata di atas tidaklah asing di kalangan akademisi yaitu suatu istilah untuk penyandang lulusan terbaik di atas standar nilai yang ditentukan. Istilah tersebut cukup lama digunakan 
dalam praktik berbahasa, tetapi kata tersebut saat ini telah memiliki padanan katanya yaitu kata 'dengan pujian'. Padanan kata tersebut telah disesuaikan dengan kata aslinya yang merupakan kata sifat, sehingga istilah dalam bahasa Indonesianya dapat diterima sebagai bentuk pemutakhiran bahasa Indonesia.

\begin{tabular}{|c|c|}
\hline Bathtub & Bathtub \\
\hline
\end{tabular}

Kata di atas sebagai contoh suatu kata yang sampai saat ini belum memiliki transliterasi atau padanan katanya. Kata tersebut tidaklah tepat jika diartikan sebagai 'bak mandi', karena kata tersebut berbeda makna dengan 'bak' yang digunakan untuk mandi. Kata bathtub sampai saat ini masih menggunakan istilah aslinya untuk digunakan dalam berkomunikasi. Hal tersebut dikarenakan istilah padanan kata untuk kata tersebut belum ditemukan sampai saat ini.

\section{Perkembangan Istilah Era Modern}

Bahasa memiliki karakteristik yang dinamis, artinya bahasa terus mengalami perubahan. Perubahan tersebut dilakukan sebagai upaya pemerkaya khazanah dan sebagai suatu bentuk pemutakhiran bahasa itu sendiri. Istilah tersebut muncul sebagai bentuk modernitas zaman yang memunculkan kosakata baru dan dianggap positif untuk diserap dalam bahasa Indonesia. Akan tetapi, sebelum menyerap suatu kata ke dalam KBBI, Pekamus akan melihat makna bahasa itu terlebih dahulu.

\begin{tabular}{|c|c|}
\hline Netizen & Warganet \\
\hline
\end{tabular}

Kata tersebut merupakan salah satu kata yang muncul dalam era modern. Kata tersebut pertama kali digunakan ketika banyaknya masyarakat yang memiliki media sosial dan menyuarakan aspirasinya di media sosial. Kata yang pertama kali digunakan adalah netizen, tetapi seiring lazimnya penggunaan kata tersebut, Pekamus pun mencarikan istilah yang sesuai dan dapat digunakan dalam bahasa Indonesia.

\begin{tabular}{|c|c|}
\hline Booming & Viral \\
\hline
\end{tabular}

Kata booming sebelumnya menjadi pilihan setiap orang dalam menyebutkan suatu hal yang sedang menjadi pembicaraan di masyarakat atau di media sosial. Akan tetapi, kata tersebut kini telah memiliki padanan kata yang dapat digunakan dan sesuai dengan kaidah bahasa Indonesia. Kata viral merupakan padanan istilah dalam bahasa Indonesia yang serupa dengan kata booming yang merupakan suatu bentuk kata sifat.

\section{SIMPULAN}

Pemutakhiran bahasa dipengaruhi oleh perkembangan zaman dan disesuaikan dengan kaidah yang berlaku di dalam bahasa Indonesia. Istilah baru digunakan sebagai upaya pengutamaan bahasa Indonesia dalam berkomunikasi di ruang publik. Munculnya kosakata asing dan kemudian dipadankan atau diserap ke dalam bahasa Indonesia menjadi bukti bahwa bahasa Indonesia memiliki kaidah pembakuan kata yang disepakati. Kata yang sudah dimutakhirkan dapat digunakan sebagai alat berkomunikasi di masyarakat maupun di media sosial. Selain itu, bentuk transliterasi, serapan, dan padanan kata dalam bahasa Indonesia memiliki perbedaan yang dapat diamati, sehingga pengguna bahasa dapat membedakan unsurnya berdasarkan bentuk penulisannya. 


\section{UCAPAN TERIMA KASIH}

Penulis mengucapakan terima kasih kepada Ketua STIE Ahmad Dahlan dan LP3M STIE Ahmad Dahlan Jakarta yang telah memfasilitasi penulis untuk berkarya. Selain itu, penulis mengucapkan terima kasih kepada rekan-rekan Jurusan Pendidikan Bahasa dan Sastra UIN Syarif Hidayatullah Jakarta yang selama ini membantu penulis dalam membuat artikel. Penulis juga mengucapkan terima kasih kepada pengelola Jurnal SeBaSa: Jurnal Pendidikan Babasa dan Sastra yang telah memublikasikan artikel ini.

\section{DAFTAR PUSTAKA}

Emzir. (2012). Metode Penelitian Kualitatif: Analisis Data. Jakarta: Rajawali Pers.

Hudaa, Syihaabul. (2017). "Peranan Lingkungan dalam Pemelajaran Bahasa Indonesia sebagai Bahasa Kedua." Disampaikan dalam Seminar Internasional di UIN Syarif Hidayatullah Jakarta.

. (2018). "Efektivitas Pembelajaran Bahasa Indonesia Menggunakan Pendekatan Student Active Learning di Jurusan Manajemen Fakultas Ekonomi dan Bisnis UIN Syarif Hidayatullah Jakarta.” Jurnal Bahastra, Vol. XXXVIII. No. 1 Mei. Publisher. . (2018). Estetika Berbahasa: Mengapresiasi Bahasa Indonesia. Sukabumi: Jejak

Pusat Bahasa. (2007). Pedoman Umum Pembentukan Istilah. Jakarta: Pusat Bahasa Departemen Pendidikan Nasional.

Sulistyowati, Indah. (2015). "Menerjemahkan Permainan Bahasa dalam Novel Anak Judy Moody, Detective.” Jurnal Retorika: Jurnal Ilmu Bahasa. Vol. 1. No. 2 Oktober. 